\title{
Comparison of absorption of nutrients and secretion of water between oligomeric and polymeric enteral diets in pigs
}

\author{
Hansjörg Ehrlein* and Benedikt Haas-Deppe \\ Institute of Physiology, University of Hohenheim, Stuttgart, Germany
}

(Received 3 March 1998 - Revised 17 June 1998 - Accepted 3 August 1998)

\begin{abstract}
In patients who require enteric tube-feeding the osmolality of the formulas is assumed to play an important role. There is the dilemma that osmolality increases as the digestibility of formulas is enhanced by means of degradation of the nutrients. Hitherto there have been no reports of whether there are differences in nutrient absorption and water fluxes between iso-osmotic polymeric and hyperosmotic oligomeric diets. We therefore investigated absorption of nutrients and net fluxes of water during perfusion of a $1.5 \mathrm{~m}$ jejunal segment with oligomeric, polymeric and commercial oligopeptide diets either in the absence of pancreatic juice or with concomitant infusion of pancreatic enzymes. In the absence of pancreatic juice the absorption rates of the polymeric diet and the commercial oligopeptide diets reached 58.0 and $84.5 \%$ respectively of that of a completely-hydrolysed hyperosmotic oligomeric diet. The concomitant infusion of pancreatic enzymes with the polymeric and oligopeptide diets significantly increased the absorption rates of nutrients and energy. The highest absorption rate of energy occurred with the commercial formula Survimed ${ }^{\circledR}$ (Fresenius, Bad Homburg, Germany), probably due to an optimal composition of the macronutrients. The increase in absorption due to the degradation of nutrients by pancreatic enzymes was associated with an increase in net water secretion and flow-rate, reaching similar values to those with the hyperosmotic oligomeric diet. It may be concluded that iso-osmotic oligopeptide formulas require further pancreatic hydrolysis for optimum absorption. In patients with normal pancreatic secretion, oligopeptide formulas have no advantage over polymeric diets. In patients with reduced pancreatic secretion, either completely-hydrolysed hyperosmotic oligomeric diets or polymeric diets supplemented with pancreatic enzymes are appropriate.
\end{abstract}

Enteral nutrition: Osmolality: Nutrient hydrolysis

In enteral nutrition there is the choice to administer diets either into the stomach or into the proximal small intestine. In most patients who require tube-feeding, administration of polymeric formulas into the stomach is appropriate (Kirby \& Fleming, 1995). Jejunal access is recommended in patients with recurrent tube-feeding aspiration, gastroparesis, and in critically-ill patients (Kirby \& Fleming, 1995; Gorman \& Morris, 1997). There are several major differences in physiological functions between gastric and enteric feeding. With gastric feeding the delivery of chyme into the small intestine is regulated by the enteric feedback mechanism, formulas of high energy density are diluted by gastric, biliary and pancreatic secretions so that the chyme entering the jejunum is iso-osmotic (Miller et al. 1978). With gastric feeding, therefore, osmolality of the diets plays no role. In contrast, with jejunal feeding the feedback control is eliminated, and the higher energy density of formulas which is required to meet the daily energy requirement without surplus of water may cause osmotic problems.
In addition to the choice of application, a large number of commercial diets are available for enteral tube-feeding (Gotteland et al. 1997). For categorization of enteral formulas, different systems were proposed. One system subdivides formulas into polymeric, oligomeric and monomeric enteral diets according to the molecular form of the nutrients (Gotteland et al. 1997). Polymeric diets contain the three macronutrients in large molecular form and consequently require digestion by pancreatic enzymes. They are recommended for patients with normal gastrointestinal function and in particular for gastric infusion of the diet. With oligomeric formulas, carbohydrate and protein have been hydrolysed to oligosaccharides and oligopeptides, thus they are also called oligopeptide diets. They require minimal pancreatic digestion and are recommended for patients with reduced digestive capacity or special intestinal diseases (Gotteland et al. 1997; McCamish et al. 1997). Monomeric formulas contain nutrients in their monomeric form, e.g. glucose and amino acids. In enteric feeding there is the 
dilemma that with increasing degree of hydrolysis and digestibility of the nutrients the osmolality of the diets also increases. This is a particular problem with enteric feeding because of the high energy density required with the enteral diets. The monomeric formulas are characterized by a high osmolality. With oligomeric diets the osmolality depends on the degree of hydrolysis of carbohydrate and protein. The endproducts of pancreatic degradation are mainly oligopeptides and oligosaccharides. With a diet of high energy density these oligomers already produce a high osmolality. Thus, the nutrients of commercial oligomeric diets are only partially hydrolysed and oligomeric diets therefore represent a compromise between facilitating assimilation and absorption of nutrients and limiting the increase in osmolality. In a previous study it was shown that a starch hydrolysate of low molecular weight containing a glucose polymer fraction of up to ten glucose molecules can be absorbed in the absence of pancreatic enzymes, and even a high-molecular-weight fraction was surprisingly well absorbed (Jones et al. 1983). However, the extent to which the three macronutrients of approximately iso-osmotic commercial oligomeric formulas can be absorbed without further hydrolysis by pancreatic enzymes in comparison with a highly-hydrolysed hyperosmotic oligomeric diet has not been investigated. It is generally accepted that high osmolality of enteral diets should be avoided because it may affect its tolerance and produce gastrointestinal sequelae (Gotteland et al. 1997). However, it remains to be determined whether low osmolality of oligomeric diets is really of advantage in enteric feeding. We hypothesize that an iso-osmotic oligopeptide diet may require further pancreatic degradation of the nutrients, and thus osmolality of the chyme may increase to a similar extent to that with an absorbable hyperosmotic oligomeric diet.

Thus, the aim of the present study was to clarify these unsolved questions. In unanaesthetized minipigs, absorption of nutrients and energy, net flux of water and flow-rates were measured by perfusing a $1.5 \mathrm{~m}$ jejunal segment with a hyperosmotic oligomeric diet (in which the three macronutrients are hydrolysed to such an extent that further pancreatic degradation is not required), a polymeric diet (in which the three macronutrients are in large molecular form), and three approximately iso-osmotic commercial oligopeptide diets (formulas containing oligopeptides and oligosaccharides) with different ratios of the three macronutrients. Absorption rates were measured in the absence of pancreatic juice and during concomitant infusion of pancreatic juice.

\section{Materials and methods}

Studies were performed in five female 'Troll' minipigs weighing $44-50 \mathrm{~kg}$. The animals were fed twice daily with a diet containing (\% energy): 75 as carbohydrate, 15 as protein, 10 as fat. The energy supply was $7000 \mathrm{~kJ} / \mathrm{d}$, corresponding to $400 \mathrm{~kJ} / \mathrm{kg}$ body weight ${ }^{0.75}$.

\section{Surgical procedures}

The procedures used in the present study were approved by the Animal Care Committee of the 'Regierungspräsidium'
Stuttgart, Germany. Surgical procedures were performed under general anaesthesia with tiletamine and zolazepam $\left(1: 1, \quad w / w ; \quad\right.$ Tilest $^{\circledR} ;$ Parke-Davis, Berlin, Germany; $6 \mathrm{mg} / \mathrm{kg}$ intramuscularly) and halothane in $\mathrm{O}_{2}-\mathrm{N}_{2} \mathrm{O}$ $(0 \cdot 5: 49 \cdot 75: 49 \cdot 75-1 \cdot 0: 49 \cdot 5: 49 \cdot 5$, by vol.). Three cannulas made of silicone rubber (Elastosil ${ }^{\circledR}$ R401/70E; Wacker, Munich, Germany) were implanted into the proximal jejunum at 1,2 and $3.65 \mathrm{~m}$ distal to the ligament of Treitz. The cannulas were exteriorized through the right abdominal wall. The intraluminal base of the cannulas was positioned at the abdominal wall in a ventro-dorsal direction. The upward flow of digesta facilitated the outflow of chyme through the opened cannulas.

\section{Measurement of nutrient absorption and net flux of water}

The jejunal segment located between the middle and the distal cannulas was perfused with different enteral diets. For this purpose, a balloon catheter was inserted into the mid-cannula. The tip of the catheter was positioned $150 \mathrm{~mm}$ aboral of the cannula. Thus, the length of the jejunal test segment was $1.5 \mathrm{~m}$. The residues of the infused enteral diets were drained by the distal cannula, whereas the chyme emptying from the stomach, bile and pancreatic secretion were drained by the proximal cannula. Absorption of nutrients and net fluxes of water were measured by the differences between infused and recovered nutrients or water according to the equation described by Modigliani et al. (1973):

$$
\begin{aligned}
\text { absorption }_{\text {nutrient }}= & \text { nutrient }_{\text {infused }}-\text { nutrient }_{\text {recovered }} \\
& \times \frac{\text { marker }_{\text {infused }}}{\text { marker }_{\text {recovered }}}
\end{aligned}
$$

All diets were supplemented with the non-absorbable marker Co-EDTA $(50 \mathrm{mg} / \mathrm{l})$.

\section{Enteral diets}

Five enteral diets were used, three commercial diets and two self-made diets. The commercial diets were oligopeptide diets: Peptisorb ${ }^{\circledR}$ (Pfrimmer, Erlangen, Germany), Survimed $^{\circledR}$ (Fresenius, Bad Homburg, Germany), and Salvipeptid $^{\circledR}$ (Clintec Salvia, Nuremberg, Germany). The composition of these oligopeptide diets differed markedly both in the ratio and the amounts of carbohydrate, protein and fat (Table 1). Peptisorb ${ }^{\circledR}$ contains large amounts of carbohydrate and small amounts of fat, whereas Salvipeptid ${ }^{\circledR}$ contains large amounts of fat and small amounts of carbohydrate. Survimed ${ }^{\circledR}$ has an intermediate composition of nutrients (Table 1). The degradation of carbohydrate and protein also differed among the three commercial formulas (Fig. 1). With Peptisorb ${ }^{\circledR}$ and Salvipeptid ${ }^{\circledR}$, starch was hydrolysed to a larger extent than with Survimed ${ }^{\circledR}$, whereas the extent of hydrolysis of protein was higher with Survimed $^{\circledR}$ and lower with Peptisorb ${ }^{\circledR}$ and Salvipeptid ${ }^{\circledR}$. The diets originally had an energy density of $4.2 \mathrm{~kJ}(1 \mathrm{kcal}) /$ $\mathrm{ml}$. The energy density was reduced to $3.4 \mathrm{~kJ}(0.8 \mathrm{kcal}) / \mathrm{ml}$ in order to be able to add bile, pancreatic juice, and the Co-EDTA marker. The diets were infused into the jejunal segment either without or with bile and pancreatic enzymes. 
Table 1. Composition and osmolality of the enteral diets

\begin{tabular}{|c|c|c|c|c|c|c|c|c|c|c|c|c|c|c|}
\hline \multirow[b]{2}{*}{ Diets } & \multicolumn{3}{|c|}{$\begin{array}{l}\text { Ratio of } \\
\text { macronutrients } \\
\text { (\% energy) }\end{array}$} & \multicolumn{3}{|c|}{$\begin{array}{l}\text { Amounts of } \\
\text { macronutrients } \\
(\mathrm{g} / \mathrm{l})\end{array}$} & \multicolumn{6}{|c|}{$\begin{array}{l}\text { Concentrations of electrolytes } \\
\qquad(\mathrm{mmol} / \mathrm{l})\end{array}$} & \multicolumn{2}{|c|}{$\begin{array}{l}\text { Osmolality } \\
\text { (mosmol/kg) }\end{array}$} \\
\hline & $\mathrm{CHO}$ & Protein & Fat & $\mathrm{CHO}$ & Protein & Fat & $\mathrm{Na}^{+}$ & $\mathrm{K}^{+}$ & $\mathrm{Ca}^{2+}$ & $\mathrm{Mg}^{2+}$ & $\mathrm{Cl}^{-}$ & $\mathrm{PO}_{4}{ }^{3-}$ & Before†† & After†† \\
\hline Oligomeric* & 75 & 15 & 10 & 155.4 & $25 \cdot 2$ & $7 \cdot 3 \S$ & 120 & $6 \cdot 7$ & 5.5 & 0.4 & 99.4 & $4 \cdot 1$ & 780 & 780 \\
\hline Polymeric† & 75 & 15 & 10 & 159.5 & $22 \cdot 1$ & $7 \cdot 3 \|$ & 120 & 1.0 & 0.9 & 0.2 & 60.5 & 0.2 & 440 & 718 \\
\hline Peptisorb $^{\circledR} \neq$ & 75 & 15 & 10 & 150 & 30 & 8.8 & $120^{* *}(60)$ & 30 & 12.5 & $7 . \overline{5}$ & $87^{* *}(27)$ & 20 & 440 & 706 \\
\hline Survimed $^{\circledR} \mp$ & 60 & 18 & 22 & 10 & 36 & 20.8 & $120^{* *}(44)$ & 32 & 15 & 8 & $93^{* *}(33)$ & 16 & 550 & 810 \\
\hline Salvipeptid $^{\circledR} \ddagger$ & 54 & 19 & 27 & 108 & 38 & 24 & $120^{* *}(45)$ & 45 & 10 & $7 \cdot 4$ & $105^{\star \star}(45)$ & 12.9 & 400 & 679 \\
\hline
\end{tabular}

$\mathrm{CHO}$, carbohydrate.

* Diet in which the three macronutrients are hydrolysed to such an extent that further pancreatic degradation is not required.

† Diet in which the three macronutrients are in large molecule form.

‡ Commercial formulas containing oligopeptides and oligosaccharides; for details of sources, see pp. 546-548.

$\S$ Micellar suspension of partially-hydrolysed triacylglycerol derived from an emulsion of triacylglycerol (Lipovenös; Fresenius, Bad Homburg, Germany); for details of procedure, see pp. 546-548.

|| Lipovenös.

- Contains ( $\mathrm{g} / 100 \mathrm{~g}$ fat): long-chain triacylglycerols 50, medium-chain triacylglycerols 50 .

** After adjustment of $\mathrm{Na}$ to $120 \mathrm{mmol} / \mathrm{l}$.

††Before and after in vitro hydrolysis.

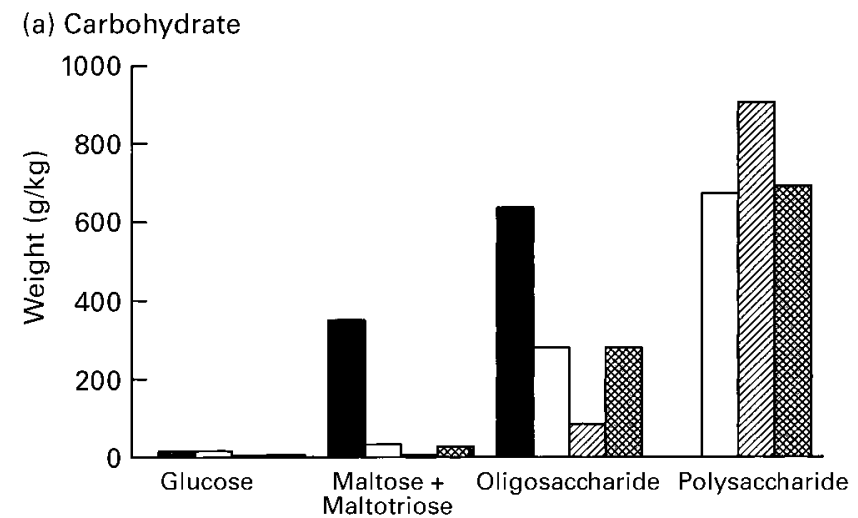

(b) Protein

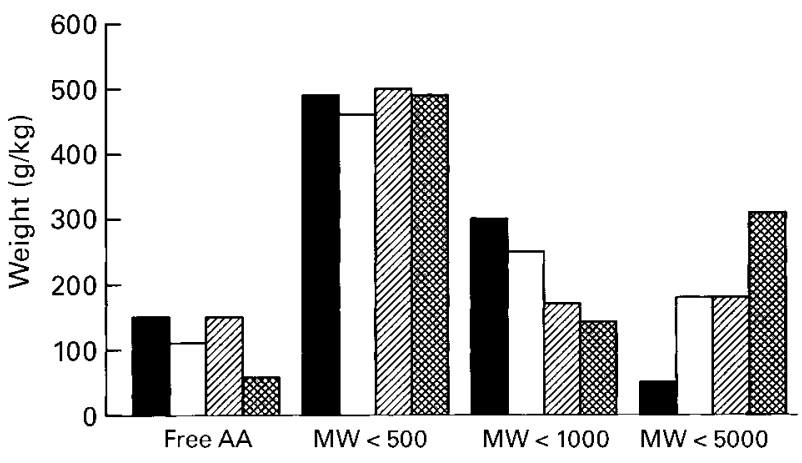

Fig. 1. Degree of hydrolysis of carbohydrate (a) and protein (b) of the oligomeric diet $(\boldsymbol{\square})$ and the three commercial oligopeptide formulas. The oligomeric diet is characterized by high degradation of both carbohydrate and protein. Survimed ${ }^{\circledR}$ (Fresenius, Bad Homburg, Germany; $\nabla \Delta$ ) is characterized by high degradation of protein and low degradation of carbohydrate, whereas Peptisorb ${ }^{\circledR}$ (Pfrimmer, Erlangen, Germany; $\square$ ) and Salvipeptid ${ }^{\circledR}$ (Clintec Salvia, Nuremberg, Germany; are characterized by high degradation of carbohydrate and low degradation of protein. AA, amino acid; MW, molecular weight. For details of composition of diets, see Table 1.
In those experiments in which no bile and pancreatic enzymes were added, the commercial diets were diluted to $3.4 \mathrm{~kJ} / \mathrm{ml}$ with distilled water.

The bile was produced by dissolving $15 \mathrm{~g}$ bile extract (B-8631; Sigma, St Louis, MO, USA) in $100 \mathrm{ml}$ distilled water. Bile solution $(1.82 \mathrm{~g})$ was added to $100 \mathrm{ml}$ diet. The pancreatic solution consisted of 3.33 g Pancreatin ${ }^{\circledR}$ (P-1750; Sigma) dissolved in $100 \mathrm{ml}$ distilled water. The commercial diets and the pancreatic solution were infused into the jejunum using separate pumps (KP 2000; Desaga, Heidelberg, Germany) so that hydrolysis of the nutrients commenced in the small intestine. Pancreatic solution $(0.5 \mathrm{ml})$ was added to $2.0 \mathrm{ml}$ diet resulting in a Pancreatin ${ }^{\circledR}$ concentration of $4.4 \mathrm{~g} / \mathrm{l}$ solution.

Additionally, two self-made enteral diets were used: an oligomeric and a polymeric diet. The compositions of nutrients and of electrolytes are summarized in Table 1. For both diets the ratio (\% energy) for carbohydrate, protein and fat was 75:15:10 respectively. This ratio of nutrients was identical with that of the commercial diet Peptisorb ${ }^{\circledR}$ (Table 1).

The carbohydrate in the oligomeric diet consisted of maltodextrin (C-Pur ${ }^{\circledR}$ 1934; Cerestar, Krefeld, Germany) which comprised $(\mathrm{g} / \mathrm{kg})$ : glucose 15 , maltose 350 , maltotriose 210, oligosaccharides 425 (Fig. 1). The protein consisted of hydrolysed whey protein (Hyprol $8080^{\circledR}$; Quest International, Zwijndrecht, The Netherlands) which comprised (g/kg): amino acids 150, di- and tripeptides 500, oligopeptides 300, polypeptides 50 (Fig. 1). A commercial emulsion of triacylglycerol (Lipovenös ${ }^{\circledR}, 100 \mathrm{ml} / \mathrm{l}$; Fresenius) was used as the fat component. Before intestinal perfusion the fat emulsion was hydrolysed in vitro by pancreatic enzymes. For this purpose, $66.7 \mathrm{~g}$ Lipovenös ${ }^{\circledR}$ were mixed with $6.7 \mathrm{mg}$ cholesterol (C-3292; Sigma), $623 \mathrm{mg}$ bile salts (B-8756; Sigma), $667 \mathrm{mg}$ Pancreatin ${ }^{\circledR}$ (P-1750, Sigma) and small amounts of distilled water. During the hydrolysis at $37^{\circ}$ the $\mathrm{pH}$ was kept at 7.0 by pH-stat (Titrator D3; Metrohm, Herisau, Switzerland) titration with $0.3 \mathrm{M}-\mathrm{NaOH}$. After the addition of $20 \mathrm{ml} \mathrm{NaOH}$, the hydrolysis was stopped by cooling, and distilled water 
was added to produce a final weight of $100 \mathrm{~g}$. The hydrolysed fat solution represented a micellar suspension. It was composed of $(\mathrm{g} / \mathrm{kg})$ : free fatty acids 487 , monoacylglycerol 247 , diacylglycerol 131, triacylglycerol 135 . In comparison with the commercial oligopeptide diets the nutrients of the self-made oligomeric diet were hydrolysed to a larger extent (Fig. 1). Consequently, the osmolality of the self-made oligomeric diet was much higher (Table 1). Preliminary experiments showed that replacing the oligosaccharide with maltose did not enhance the absorption rate, whereas replacement with glucose reduced the absorption rate. Additionally, the concomitant infusion of pancreatic enzymes did not enhance the absorption rate of energy, i.e. hydrolysis by the brush-border enzymes was sufficient for absorption of the three nutrients. Thus, with the oligomeric diet the degradation of the three nutrients provided maximal absorption rates for the nutrients and of energy. The carbohydrate-protein solution and the micellar fat suspension were infused using separate pumps because the solution containing all three components was unstable. The energy density was $3.18 \mathrm{~kJ}(0.8 \mathrm{kcal}) / \mathrm{ml}$.

The polymeric diet was composed of soluble starch (C-Pur ${ }^{\circledR}$ 1905; Cerestar, Krefeld), lactalbumin and an emulsion of triacylglycerol (Lipovenös ${ }^{\circledR}, 100 \mathrm{ml} / \mathrm{l}$; Fresenius; Table 1).

The Na concentration of all five solutions was adjusted to $120 \mathrm{mmol} / \mathrm{l}$ so that absorption of nutrients was not influenced by a possible deficiency of $\mathrm{Na}$. The concentrations of the other electrolytes varied slightly among the commercial diets (Table 1). With the self-made oligomeric and polymeric diet the concentrations of these electrolytes were small (Table 1).

\section{Experimental procedure}

At the onset of each experiment the cannulas were opened and a balloon catheter was inserted into the middle cannula. The balloon was inflated with air using a pump at a constant pressure of $250 \mathrm{~mm}$ water. The corresponding volume of the balloon varied from 5 to $15 \mathrm{ml}$, resulting in a diameter for the balloon of between 10 and $20 \mathrm{~mm}$. The experimental session lasted $90 \mathrm{~min}$ and was divided into three periods: $-30-0 \mathrm{~min}$ was the equilibration period, $0-60 \mathrm{~min}$ was the test period (steady-state), and 60-90 min was the markerrecovery period. At the onset of the test period (time 0 ) a test meal was fed. During the $60 \mathrm{~min}$ test period the absorption rates of nutrients and energy were measured. From -3060 min one of the diets was infused into the jejunal segment via the balloon catheter. The residues of the diets remaining unabsorbed were drained from the distal cannula. During the marker-recovery period the test segment was perfused with saline $(9 \mathrm{~g} \mathrm{NaCl} / \mathrm{l})$. The infusion rate of all diets into the jejunal segment was $2.5 \mathrm{ml} / \mathrm{min}$, including infusion of pancreatic enzymes. Since the energy density was $3.4 \mathrm{~kJ}$ $(0.8 \mathrm{kcal}) / \mathrm{ml}$ the energy supply was $8.4 \mathrm{~kJ}(2 \mathrm{kcal}) / \mathrm{min}$. The three commercial oligopeptide diets and the polymeric diet were infused either with or without pancreatic enzymes, whereas the oligomeric diet was always infused without pancreatic enzymes. Thus, nine different experiments were performed. The sequence of the diets was selected in random order. The mean recoveries of the Co marker during the $60 \mathrm{~min}$ test period and the complete experiment were 97.3 (SD 6.4) and 95.2 (SD 6.7) \% respectively. At the mid-point of the test period, transit time was measured by injection of a $0.5 \mathrm{ml}$ bolus $(5 \mathrm{mg}$ ) Cr-EDTA into the jejunal segment. During the subsequent period the effluent of the distal cannula was collected in short intervals for recovery of the transit marker.

At the onset of the test period (time 0 ) the animals were given a test meal to induce postprandial conditions. The meal was eaten within 2 min. The energy of the meal $(3485 \mathrm{~kJ})$ met half of the daily requirement. The meal was drained by the proximal cannula as it emptied from the stomach. Consequently, bile and pancreatic juice did not enter the jejunal test segment during the experiment.

\section{Analysis of nutrients, energy and marker}

The concentrations of nutrients (carbohydrate, protein, and fat) and of the Co marker, and the energy density were determined in the diets and the effluent of the distal cannula. The samples for the analysis were homogenized by ultrasound (Sonopuls HD 200; Bandelin, Berlin, Germany).

The concentration of carbohydrate was determined using a commercial kit (starch-test; Boehringer, Mannheim, Germany). The content of protein was determined using an automatic $\mathrm{N}$ analyser (Macro-N; Heraeus, Hanau, Germany). The fat was extracted with light petroleum $\left(40^{\circ}-60^{\circ}\right)$ after hydrolysis of carbohydrate and protein with $8 \mathrm{M}-\mathrm{HCl}$. Fat extraction was performed using a semiautomatic device (Soxtherm; Gerhardt, Bonn, Germany). The fat content was determined by weighing the extracted fat. The energy densities of the diets and of the intestinal effluents were determined as the sum of the energy of each macronutrient. The conversion values used to calculate the energy contribution of the macronutrients $(\mathrm{kJ})$ are summarized in Table 2.

The concentrations of $\mathrm{Co}$ and $\mathrm{Cr}$ were measured by atomic absorption spectrometry (Perkin Elmer, Überlingen, Germany).

\section{Transit time and flow-rate}

The mean transit time of a bolus was determined as the time interval between the injection of the Cr-EDTA marker and the recovery of $50 \%$ of the marker in the effluent of the distal cannula. The flow-rate $(\mathrm{ml} / \mathrm{min})$ was defined as the volume of fluid passing the jejunal segment per min. It

Table 2. Conversion values used to calculate the energy contribution of macronutrients $(\mathrm{kJ})$ in the two self-made diets (oligomeric and polymeric) and three commercial formulas used*

\begin{tabular}{lccc}
\hline Diets & Carbohydrate $(\mathrm{kJ} / \mathrm{g})$ & Protein $(\mathrm{kJ} / \mathrm{g})$ & Fat $(\mathrm{kJ} / \mathrm{g})$ \\
\hline Oligomeric & 18.5 & 22.93 & 45.43 \\
Polymeric & 18.69 & 26.11 & 45.53 \\
Survimed $^{\circledR}$ & 18.79 & 23.12 & 40.47 \\
Salvipeptid $^{\circledR}$ & 18.3 & 26.01 & 40.47 \\
Peptisorb $^{\circledR}$ & 17.82 & 26.01 & 40.47 \\
\hline
\end{tabular}

*For details of composition and sources, see Table 1 and pp. 546-548. 
(a) Without pancreatic enzymes

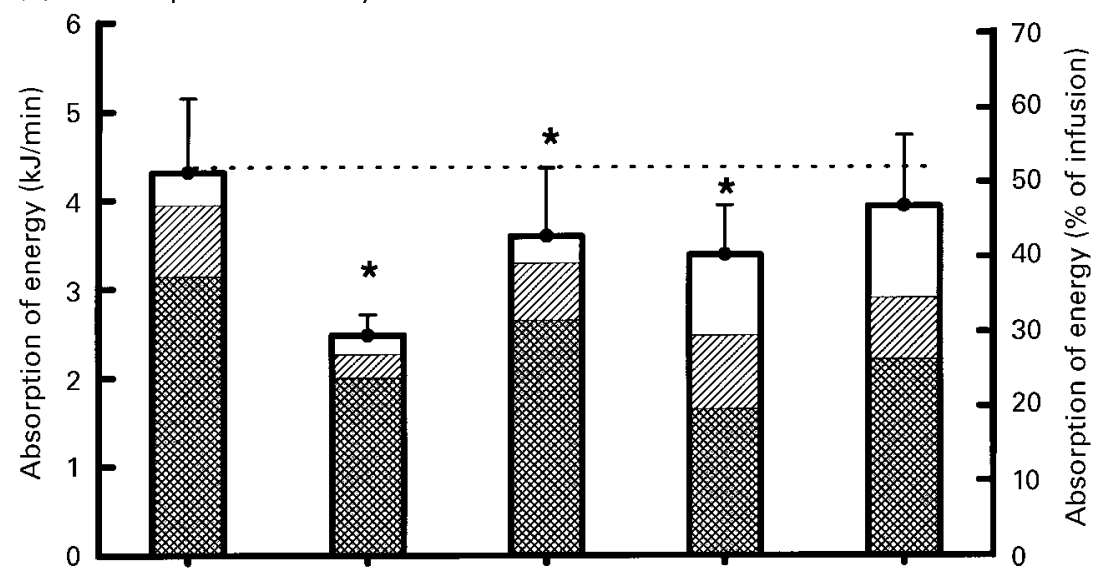

(b) With pancreatic enzymes

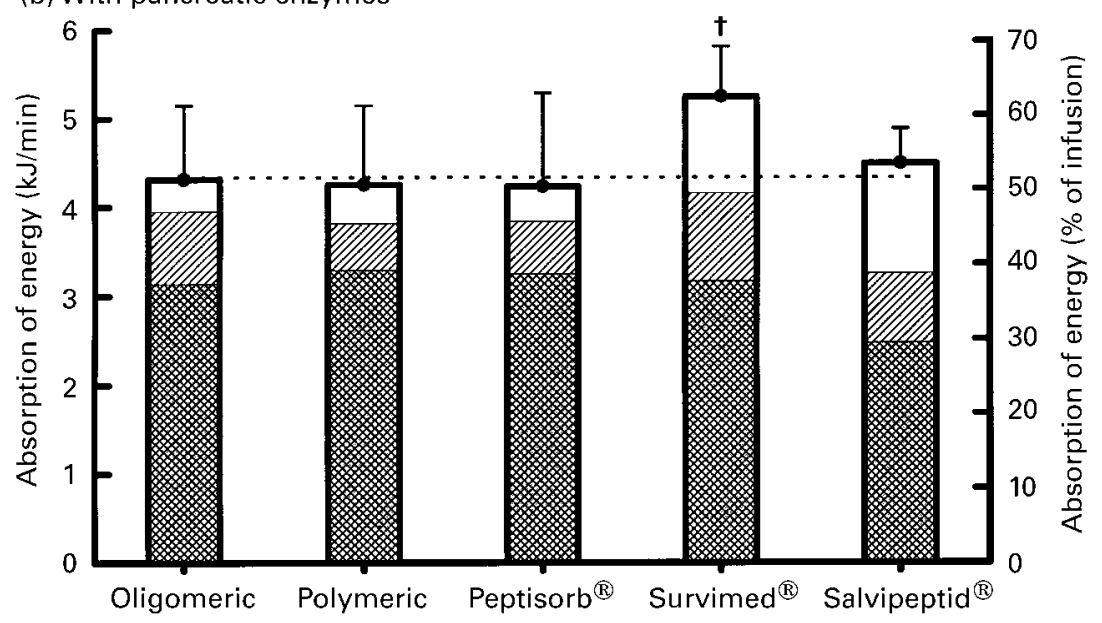

Fig. 2. Absorption rates of carbohydrate (ख), protein (ש), fat $(\square)$ and total energy during perfusion of two self-made diets and three commercial formulas without (a) and with (b) pancreatic enzymes (Pancreatin ${ }^{\circledR}$; Sigma, St Louis, MO, USA) in pigs. Values are means and standard deviations represented by vertical bars for five pigs. Mean values were significantly different from those for the oligomeric diet: ${ }^{*} P<0.05$. Mean values were significantly different from those for the other diets: $\dagger P<0.05$. For details of composition and sources of diets, see Table 1 and pp. 546-548. For details of animals and procedures, see pp. 546-549.

was determined from the equation:

$$
\text { flow-rate }(\mathrm{ml} / \mathrm{min})=\text { volume }_{\text {effluent }} \times \frac{\text { marker }_{\text {infused }}}{\text { marker }_{\text {recovered }}}
$$

where volume effluent $_{\text {is }}$ the volume recovered at the distal cannula, marker $_{\text {infused }}$ and marker ${ }_{\text {recovered }}$ are the amounts of marker which were infused and recovered during the $60 \mathrm{~min}$ test period.

\section{In vitro hydrolysis of enteral diets}

Nutrients entering the small intestine are rapidly hydrolysed by pancreatic enzymes. In the jejunal study segment, hydrolysis of the polymeric diets was caused by the concomitant infusion of pancreatic enzymes. The degradation of carbohydrate and protein increases the osmolality. In order to determine the time-course and the level of changes in osmolality occurring in the gut, the three commercial oligopeptide diets and the polymeric diet were hydrolysed in vitro by pancreatic enzymes. As in the in vivo experiments, $5 \mathrm{ml}$ of a Pancreatin ${ }^{\otimes}$ solution $(33.3 \mathrm{~g} / \mathrm{l})$ was added to $20 \mathrm{ml}$ diet. The solution was kept at $37^{\circ}$. Over a $30 \mathrm{~min}$ period samples were taken in $1 \mathrm{~min}$ intervals and the osmolality was measured immediately using an osmometer (OM 801; Vogel, Giessen, Germany). Three experiments were performed with each diet.

\section{Statistics}

For each pig, two experiments were performed with each of the nine different diets and procedures. From the data of the two experiments a mean value was calculated. Values are presented as grand means and standard deviations for data from the five pigs. A paired $t$ test was used to compare absorption of nutrients during infusion of diets either with or without pancreatic enzymes. Differences in absorption rates of energy and nutrients, and net flux of water, and differences in flow-rate and transit time among the diets were analysed using ANOVA. A probability value of $P<0.05$ was considered significant. 
Table 3. Absorption of energy and macronutrients from two self-made diets (oligomeric and polymeric) and three commercial diets $\ddagger$ infused with or without pancreatic enzymes (Pancreatin $\left.{ }^{\circledR}\right) \S$ in pigs $\|$

(Mean values and standard deviations for five pigs)

\begin{tabular}{|c|c|c|c|c|c|c|c|c|c|c|c|c|}
\hline \multirow[b]{3}{*}{ Enteral diets } & \multicolumn{12}{|c|}{ Absorption of: } \\
\hline & \multicolumn{2}{|c|}{$\mathrm{kJ} / \mathrm{min}$} & \multirow[b]{2}{*}{$\%$ षा } & \multicolumn{2}{|c|}{$\mathrm{kJ} / \mathrm{min}$} & \multirow[b]{2}{*}{$\%$} & \multicolumn{2}{|c|}{$\mathrm{kJ} / \mathrm{min}$} & \multirow[b]{2}{*}{$\%$} & \multicolumn{2}{|c|}{$\mathrm{kJ} / \mathrm{min}$} & \multirow[b]{2}{*}{$\%$ \% } \\
\hline & Mean & SD & & Mean & SD & & Mean & SD & & Mean & SD & \\
\hline Oligomeric diet & 4.31 & 0.48 & $51 \cdot 3$ & 3.14 & 0.67 & $49 \cdot 8$ & 0.81 & $0 \cdot 11$ & 64.3 & 0.37 & $0 \cdot 10$ & 44.0 \\
\hline+ Pancreatin $^{\circledR}$ & $4 \cdot 23^{*}$ & 1.06 & $50 \cdot 4$ & $3 \cdot 25^{\star}$ & 0.86 & 51.6 & $0.59^{*}$ & 0.23 & $46 \cdot 8$ & $0.39^{*}$ & 0.07 & $46 \cdot 4$ \\
\hline Survimed $^{\circledR}$ : Alone & $3.38 \dagger$ & 0.56 & $40 \cdot 2$ & 1.65 & 0.38 & 32.7 & 0.83 & 0.19 & 54.9 & 0.90 & 0.13 & $48 \cdot 7$ \\
\hline + Pancreatin ${ }^{\circledR}$ & $5.25 t$ & 0.57 & 62.5 & $3 \cdot 17^{*}$ & 0.40 & 62.9 & $0.99^{*}$ & $0 \cdot 17$ & 65.1 & $1 \cdot 10^{*}$ & 0.13 & 65.5 \\
\hline Salvipeptid ${ }^{\circledR}$ : Alone & 3.93 & 0.80 & $46 \cdot 8$ & $2 \cdot 21$ & 0.67 & 48.7 & 0.69 & 0.15 & 43.2 & 1.03 & 0.15 & $45 \cdot 4$ \\
\hline+ Pancreatin $^{\circledR}$ & $4.49^{*}$ & 0.88 & 53.5 & $2.48^{*}$ & 0.68 & 54.6 & 0.78 & 0.18 & 48.9 & 1.23 & 0.16 & $54 \cdot 2$ \\
\hline
\end{tabular}

Mean values were significantly different from those for the diet without infusion of Pancreatin ${ }^{\circledR}:{ }^{*} P<0.05$.

Mean values were significantly different from those for the oligomeric diet: $\uparrow P<0.05$.

$\ddagger$ For details of composition of diets and sources, see Table 1 and pp. 546-548.

§ Sigma, St Louis, MO, USA.

\| For details of animals and procedures, see pp. 546-549.

IPercentage of infused total energy or of infused energy as carbohydrate, protein or fat.

\section{Results}

\section{Absorption of energy and nutrients}

With the oligomeric diet $4.3 \mathrm{~kJ} / \mathrm{min}$ were absorbed along the $1.5 \mathrm{~m}$ jejunal segment, which corresponded to $51 \%$ of the energy that was infused into the jejunal segment (Fig. 2). During the infusion of the polymeric diet without pancreatic enzymes, only $2.5 \mathrm{~kJ} / \mathrm{min}$ were absorbed, corresponding to $58 \%$ of the absorption of the oligomeric diet. With the commercial oligopeptide diets Peptisorb $^{\circledR}$, Survimed $^{\circledR}$ and Salvipeptid ${ }^{\circledR}$ the absorption rates of energy were $3 \cdot 6,3 \cdot 4$ and $3.9 \mathrm{~kJ} / \mathrm{min}$ respectively (Fig. 2). These values corresponded to $83.7,79.0$, and 90.7 (mean 84.5 ) $\%$ of the absorption of the oligomeric diet respectively. The differences in absorption rates of energy between the oligomeric diet and both the polymeric and the commercial oligopeptide diets, with exception of Salvipeptid ${ }^{\circledR}$, were significant $(P<0.05$; Table 3$)$. The absorption rates of carbohydrate, protein and fat could only be compared among the oligomeric, polymeric and the oligopeptide diet Peptisorb ${ }^{\circledR}$, because these diets had the same composition of nutrients. In comparison with the oligomeric diet the absorption rates of the three nutrients were significantly $(P<0.05)$ smaller with the polymeric diet and with Peptisorb ${ }^{\circledR}$ (Table 3).

When pancreatic enzymes were concomitantly infused with the polymeric diet and the commercial oligopeptide diets, the absorption rates of total energy and of the three nutrients increased significantly $(P<0.05$; Table 3$)$. The absorption rates of total energy now reached the same values as that of oligomeric diet (Fig. 2). With the commercial diet Survimed $^{\circledR}$ the concomitant infusion of pancreatic enzymes markedly increased the absorption rates of all three nutrients, in particular of carbohydrate, resulting in a significantly larger absorption rate of total energy in comparison with all other diets (Fig. 2 and Table 3).

\section{In vitro hydrolysis of enteral diets}

The in vitro hydrolysis of the polymeric and the oligopeptide diets by pancreatic enzymes showed a rapid and large increase in osmolality within a few minutes, approaching plateau values after $30 \mathrm{~min}$. The osmolality occurring in the gut due to hydrolysis will depend on the transit time.

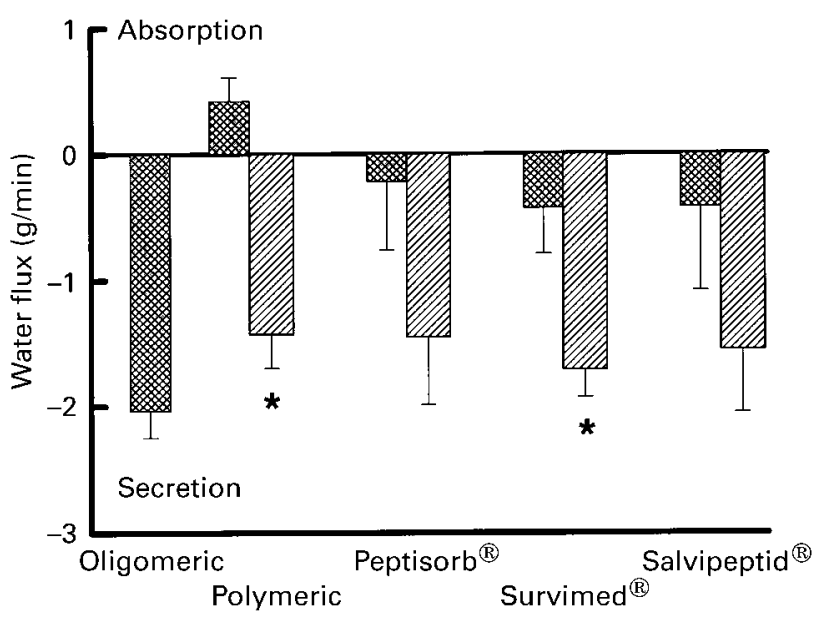

Fig. 3. Net fluxes of water during perfusion of the two self-made diets and three commercial formulas without (ख) and with (ש) concomitant infusion of pancreatic enzymes (Pancreatin ${ }^{\circledR}$; Sigma, St Louis, MO, USA) in pigs. Without infusion of pancreatic enzymes the polymeric diet produced net water absorption, whereas the commercial oligopeptide diets produced low net secretion of water. With concomitant infusion of pancreatic enzymes net water secretion increased markedly reaching similar values to those with the hyperosmotic oligomeric diet. Values are means and standard deviations represented by vertical bars for five pigs. Mean values were significantly different from that for the oligomeric diet: ${ }^{*} P<0.05$. For details of composition and sources of diets, see Table 1 and pp. 546-548. For details of animals and procedures, see pp. 546-549. 
(a)

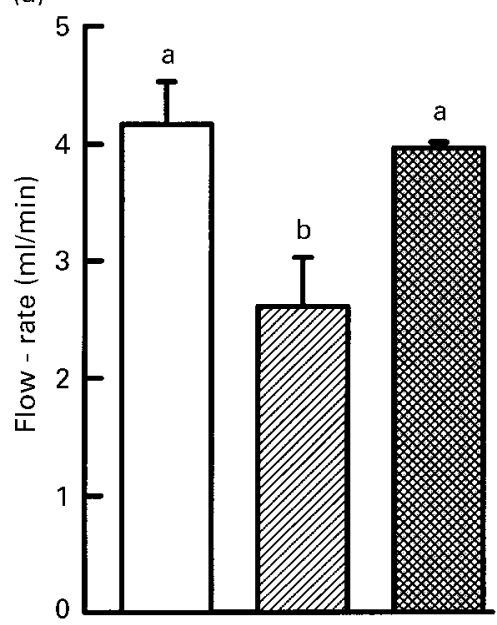

(b)

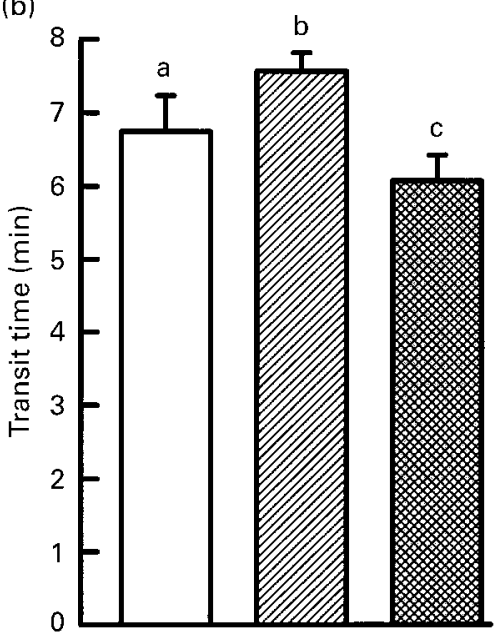

Fig. 4. Differences in flow-rate (a) and transit time (b) between the hyperosmotic oligomeric diet ( $\square$ ) and the polymeric and three commercial oligopeptide formulas infused without (ש) or with (ख) pancreatic enzymes (Pancreatin ${ }^{\circledR}$; Sigma, St Louis, MO, USA) in pigs. Values are means and standard deviations represented by vertical bars for five pigs. ${ }^{a, b, c}$ Mean values with different superscript letters were significantly different $(P<0.05)$. For details of composition and sources of diets, see Table 1 and pp. 546-548. For details of animals and diets, see pp. 546-548.

Thus, the osmolality of the in vitro hydrolysis was evaluated after a period corresponding to the mean transit time with each diet. This value might resemble the osmolality occurring in the jejunal segment by hydrolysis of the polymeric or oligopeptide diets. The osmolality after hydrolysis of the polymeric and oligopeptide diets is summarized in Table 1. It was in the range of that of the oligomeric diet.

\section{Net flux of water, flow-rate of chyme and transit time}

The perfusion of the polymeric diet was associated with net absorption of water (Fig. 3). In contrast, the oligomeric diet produced a pronounced net secretion of water due to its

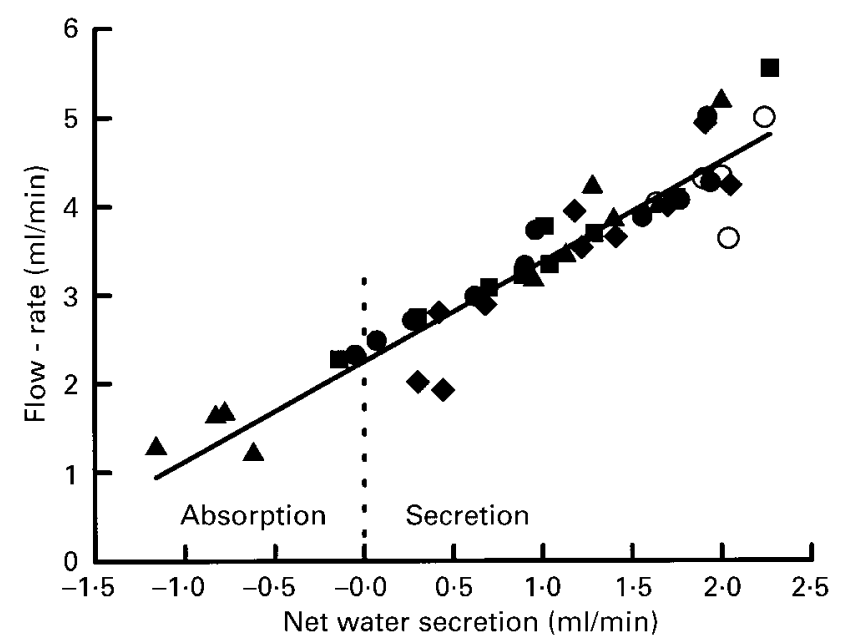

Fig. 5. Close linear relationship between net secretion of water and flow-rate during perfusion of oligomeric $(\bigcirc)$, polymeric $(\boldsymbol{\Lambda})$ and three commercial oligopeptide formulas (Peptisorb ${ }^{\circledR}(\boldsymbol{\square})$, Survimed ${ }^{\circledR}(\bullet)$ and Salvipeptid $\left.^{\circledR}(\bullet)\right)$ in pigs. Negative values represent net absorption of water. Flow-rate $(\mathrm{ml} / \mathrm{min})=2.25+1.13 \times$ net water flux $(\mathrm{ml} /$ $\min$ ); $r 0.92$. For details of composition of diets, see Table 1 and pp. 546-548. For details of animals and diets, see pp. 546-548. high osmolality. The commercial oligopeptide diets were also associated with a small net secretion of water. The addition of pancreatic enzymes to the polymeric and the oligopeptide diets significantly increased the net secretion of water, reflecting the increase in osmolality. The differences in net water secretion between the oligomeric diet and the polymeric and commercial diets were small, although two differences reached significance $(P<0 \cdot 05$; Fig. 3).

With the oligomeric diet the mean flow-rate of chyme at the distal cannula was $4.2(\mathrm{SD} 0.4) \mathrm{ml} / \mathrm{min}$. This flow-rate was 1.7 -fold compared with the infusion rate of $2.5 \mathrm{ml} / \mathrm{min}$. The perfusion of the polymeric and the oligopeptide diets without concomitant infusion of pancreatic enzymes produced significantly lower flow-rates (mean 2.6 (SD 0.42) $\mathrm{ml} /$ min) at the distal cannula than the oligomeric diet $(P<0.05$; Fig. 4(a)). However, supplementing the polymeric and oligopeptide diets with pancreatic enzymes significantly $(P<0.05)$ increased the flow-rate to a value (mean 3.97 (SD 0.05$) \mathrm{ml} / \mathrm{min}$ ) similar to that of the oligomeric diet (Fig. 4(a)). The mean transit time of a marker bolus was also significantly different among the oligomeric diet and the polymeric and oligopeptide diets with or without concomitant infusion of pancreatic enzymes $(P<0.05$; Fig. 4(b)). A close linear relationship existed between net water flux and flow-rate (Fig. 5), indicating that enhanced flow-rates were primarily caused by net secretion of water. Additionally, the transit time decreased with increasing net secretion of water. However, linear regression between net flux of water and transit time did not reach significance $(P>0.05)$.

\section{Discussion}

The present study revealed several major findings: (1) in the absence of pancreatic juice the absorption rates of a polymeric diet and of commercial oligopeptide diets 
reached 58 and $84 \%$ of that of a completely-hydrolysed hyperosmotic oligomeric diet respectively; (2) concomitant infusion of pancreatic enzymes significantly increased the absorption rates of nutrients and energy; (3) the highest absorption rate of energy occurred with the commercial diet Survimed ${ }^{\circledR}$; (4) the increase in absorption due to degradation of nutrients by pancreatic enzymes was associated with an increase in net water secretion and flow-rate, reaching values similar to those with the hyperosmotic oligomeric diet.

The relatively large absorption of the polymeric diet in the absence of pancreatic juice was unexpected because pancreatic enzymes are required to hydrolyse carbohydrate, protein and triacylglycerol. Physiologically, the intestinal digestion consists of two procedures: intraluminal degradation of nutrients by pancreatic enzymes, and subsequent hydrolysis by brush-border enzymes of the enterocytes. The pancreatic lipase (EC 3.1.1.3) hydrolyses emulsified triacylglycerol to produce free fatty acids and 2-monoacylglycerol, pancreatic endo- and exopeptidases degrade protein to oligopeptides and amino acids, and $\alpha$ amylase (EC 3.2.1.1) degrades starch to oligosaccharides (maltose, maltotriose and $\alpha$-limit dextrins). The final degradation of the oligopeptides and oligosaccharides is performed by brush-border enzymes. The enterocytes produce $\alpha$-limit dextrinase (EC 3.2.1.41) and several disaccharidases, endopeptidases, aminopeptidases, carboxypeptidases and dipeptidases (Alpers, 1994). These enzymes break down the products of the pancreatic starch and protein digestion, i.e. they hydrolyse $\alpha$-limit dextrins, disaccharides, dipeptides and oligopeptides (Alpers, 1994). Thus, the degradation of polysaccharides, polypeptides and triacylglycerols by brush-border enzymes is not the normal course of events. The present finding can be explained in two ways. First, brush-border enzymes might be able to hydrolyse not only oligosaccharides and oligopeptides but also large carbohydrate and protein molecules. In particular, glucoamylase (EC 3.2.1.3) and endo-, amino- and carboxypeptidases of the brush border might be involved in the degradation of the polysaccharides and polypeptides. Second, despite diversion of pancreatic juice, pancreatic enzymes may have attached to the mucosa of the jejunal segment. Several studies observed that the intestinal mucosa contains amylase (Ugolev, 1960; Dahlquist \& Thomson, 1963; Jesuitova et al. 1964). It was postulated that pancreatic enzymes are adsorbed to the apical surface of the enterocytes in both animals (Ugolev, 1960; Dahlquist \& Thomson, 1963; Jesuitova et al. 1964) and human subjects (Fogel \& Gray, 1973), inducing a 'membrane digestion' that may be an important pathway for the digestion of starch. Since amylase is also found throughout the gastrointestinal tract in salivarectomized and pancreatectomized rats, McGeachin et al. (1958) and McGeachin \& Ford (1959) concluded that amylase is produced by the small intestine, particularly by the duodenum and jejunum. Despite elimination of the sources of amylase the rats were able to digest starch. The present findings showed that the intestinal mucosa has a considerable capacity to digest not only polymeric carbohydrate but also polypeptides and triacylglycerols, in particular medium-chain triacylglycerols. These results are in agreement with previous findings in pancreatectomized patients; despite lacking pancreatic enzymes lactalbumin was absorbed to the extent of $61 \%$ of $\mathrm{N}$ intake, indicating that the intestine plays a significant role in protein digestion (Steinhardt et al. 1989). In the present study, however, membrane digestion was not sufficient to hydrolyse the commercial oligopeptide formulas completely; in the absence of pancreatic juice the absorption rates of nutrients and energy were significantly lower in comparison with the highly-hydrolysed oligomeric diet. Additionally, the concomitant infusion of pancreatic enzymes significantly increased the absorption rates of all three nutrients as well with the commercial oligopeptide formulas as with the polymeric diet, reaching similar values to those with the oligomeric diet. These results clearly indicate that partially-hydrolysed oligopeptide formulas require further digestion by pancreatic enzymes. The enhanced absorption due to the pancreatic degradation of the nutrients was associated with a pronounced increase in net water secretion and flow-rate. The in vitro hydrolysis of the diets revealed that the rapid degradation of nutrients by pancreatic enzymes was associated with a marked increase in osmolality within a few minutes. These results provide several conclusions for enteric feeding. First, if pancreatic secretion of patients is normal, the enteric feeding of oligomeric formulas has no advantage over enteric infusion of polymeric diets. The absorption rates of energy, net secretion of water and flow-rates of chyme are similar with both diets. Second, if the pancreatic secretion of patients is reduced, polymeric and oligopeptide formulas should be supplemented with pancreatic enzymes, or a highly-hydrolysed hyperosmotic oligomeric diet should be administered. The net secretion of water due to the high osmolality of the hyperosmotic oligomeric diet was not much greater than that with the iso-osmotic oligopeptide formula because rapid luminal breakdown of the nutrients also increased osmolality and net secretion of water. Thus, the lower osmolality of enteric diets is only an apparent advantage. The increase in intestinal volume and flow-rate did not represent a pathological event. Under normal conditions the volume flow at the ligament of Treitz due to secretion of bile and pancreatic juice is about twice the volume delivered from the stomach into the duodenum (Miller et al. 1978). It is likely, therefore, that the net secretion of water occurring during enteric feeding of hyperosmotic oligomeric diets does not cause any non-physiological increase in intestinal volume.

In the present study three commercial oligopeptide diets were chosen that differed markedly in the composition and the degradation of the nutrients. In the absence of pancreatic juice the absorption rates of energy were not significantly different among the three commercial oligopeptide diets despite the large variations in nutrient composition. The concomitant infusion of pancreatic enzymes enhanced the absorption rates of all three nutrients markedly, and consequently the absorption rate of energy increased significantly. After additional hydrolysis by pancreatic enzymes the absorption rate of energy was significantly higher with the commercial formula 
Survimed ${ }^{\circledR}$ in comparison with the other diets. Due to the differences in nutrient composition, it was not possible to compare the absorption rates of the nutrients among the diets. Consequently, the causes for the higher absorption of nutrients from Survimed ${ }^{\circledR}$ cannot be explained by the present findings. We assume that the differences in energy absorption were predominantly caused by the different nutrient compositions of the diets. With the formula Survimed $^{\circledR}$ the ratio for carbohydrate, protein and fat was 60:18:22, with Peptisorb ${ }^{\circledR}$ the ratio was $75: 15: 10$, and with Salvipeptid ${ }^{\circledR}$ the ratio was 54:19:27, i.e. in comparison with Survimed $^{\circledR}$, Peptisorb ${ }^{\circledR}$ was characterized by a high concentration of carbohydrate and a low concentration of fat, whereas Salvipeptid $^{\circledR}$ was characterized by a high concentration of fat. In a previous study (Weber \& Ehrlein, 1998) we have found: (a) that the absorption of the three macronutrients showed saturation kinetics; (b) that the absorption rates differed significantly among carbohydrate, protein, and fat; (c) that interactions occurred among the three nutrients, modulating the absorption kinetics of the individual nutrients. With diets composed of $60 \%$ energy either as carbohydrate or protein, or comprising $33 \%$ of each nutrient, absorption rates of energy were independent of the nutrient composition. In contrast, with a diet containing $600 \mathrm{~g}$ fat $/ \mathrm{kg}$, absorption of energy was significantly reduced because fat inhibited the absorption of protein and carbohydrate (Weber, 1996). In the previous studies (Weber, 1996; Weber \& Ehrlein, 1998) the fat component in the diets comprised long-chain triacylglycerols. In contrast, the fat in the commercial oligopeptide diets comprised $500 \mathrm{~g}$ long-chain triacylglycerols and $500 \mathrm{~g}$ medium-chain triacylglycerols $/ \mathrm{kg}$. Since medium-chain triacylglycerols are hydrolysed and absorbed more rapidly than long-chain triacylglycerols, they may exert a stronger inhibitory effect on the absorption of carbohydrate and protein than the long-chain triacylglycerols. Consequently, with Salvipeptid ${ }^{\circledR}$ the relatively high content of medium-chain triacylglycerols may have reduced absorption of total energy, whereas the lower fat and higher carbohydrate content of Survimed ${ }^{\circledR}$ may result in greater absorption rates of all three nutrients. On the other hand, with Peptisorb $^{\circledR}$ the extremely high concentration of carbohydrate and low concentration of fat may be the reason for a limitation in the absorption of total energy. These aspects have not yet been investigated and remain to be determined.

\section{Acknowledgements}

The study was supported by the Deutsche Forschungsgemeinschaft, grant EH 64/6-4. The authors thank Ingeborg Ehrlein and Margrit Hartmann for technical assistance. We thank the companies for providing the enteral diets and the silicone elastomer for the cannulas.

\section{References}

Alpers DH (1994) Digestion and absorption of carbohydrates and proteins. In Physiology of the Gastrointestinal Tract, pp. 1723-1749 [LR Johnson, editor]. New York, NY: Raven Press.

Dahlquist A \& Thomson DL (1963) Separation and characteristics of two rat-intestinal amylases. Biochemical Journal 89, 272-277.

Fogel MR \& Gray GM (1973) Starch hydrolysis in man: an intraluminal process not requiring membrane digestion. Journal of Applied Physiology 35, 263-267.

Gorman RC \& Morris JB (1997) Minimally invasive access to the gastrointestinal tract. In Clinical Nutrition: Enteral and Tube Feeding, pp. 174-192 [JL Rombeau and RH Rolandelli, editors]. Philadelphia and London: W.B. Saunders.

Gotteland MM, Shronts EP \& Hutchins AM (1997) Defined formula diets. In Clinical Nutrition: Enteral and Tube Feeding, pp. 207-239 [JL Rombeau and RH Rolandelli, editors]. Philadelphia and London: W.B. Saunders.

Jesuitova N, DeLaey P \& Ugolev AM (1964) Digestion of starch in vivo and in vitro in a rat intestine. Biochimica et Biophysica Acta 86, 205-210.

Jones BJM, Brown BE, Loran JS, Edgerton D, Kennedy JF, Stead JA \& Silk DBA (1983) Glucose absorption from starch hydrolysates in the human jejunum. Gut 24, 1152-1160.

Kirby DF \& Fleming CR (1995) American Gastroenterological Association Medical Position Statement: Guidelines for the use of enteral nutrition. Gastroenterology 108, 1280-1301.

McCamish MA, Bounous G \& Geraghty ME (1997) History of enteral feeding: past and present perspectives. In Clinical Nutrition: Enteral and Tube Feeding, pp. 1-11 [JL Rombeau and RH Rolandelli, editors]. Philadelphia and London: W.B. Saunders.

McGeachin RL \& Ford NJ (1959) Distribution of amylase in the gastrointestinal tract of the rat. American Journal of Physiology 196, 972-974.

McGeachin RL, Gleason JR \& Adams NR (1958) Amylase distribution in extrapancreatic, extrasalivary tissues. Archives of Biochemistry and Biophysics 75, 403-411.

Miller LJ, Malagelada JR \& Go VLW (1978) Postprandial duodenal function in man. Gut 19, 699-706.

Modigliani R, Rambaud JC \& Bernier JJ (1973) The method of intraluminal perfusion of the human small intestine. 1. Principle and technique. Digestion 9, 176-192.

Steinhardt HJ, Wolf A, Jakober B, Schmuelling RM, Langer K, Brandl M, Fekl W \& Adibi SA (1989) Nitrogen absorption in pancreatectomized patients: protein versus protein hydrolysate as substrate. Journal of Laboratory and Clinical Medicine 113, $162-167$.

Ugolev AM (1960) Influence of the surface of the small intestine on enzymatic hydrolysis of starch by enzymes. Nature 188, $588-589$.

Weber E (1996) Beziehungen zwischen der Magenentleerung von Nährstoffen und der Resorptionskapazität des Dünndarms beim Schwein (Relationships between gastric emptying of nutrients and absorptive capacity of small intestine in pig). Dissertation, University of Hohenheim.

Weber E \& Ehrlein HJ (1998) Relationships between gastric emptying and intestinal absorption of nutrients and energy in minipigs. Digestive Diseases and Sciences 43 1141-1153. 


\section{Public Health Nutrition}

Essential reading for everyone involved with nutritional epidemiology research, the role of nutrition in disease prevention, and identifying practical solutions to public health problems.

1999, Volume 2, 4 issues

ISSN: 1368-9800

\section{Journal Editors}

Dr Barrie Margetts (Editor-in-Chief)

Southampton General Hospital, UK

Dr Lenore Kohlmeier (Editor, North America)

Schools of Public Health and Medicine,

University of North Carolina at Chapel Hill, USA

Dr Frans Kok

Wageningen Agricultural University, The

Netherlands

Dr Michael Nelson

University of London, UK

To order your subscription, reserve a FREE sample copy, or for more information, contact:

(10) CABI Publishing

CABI Publishing, CAB International,

Wallingford, Oxon, OX10 8DE, UK

Tel: +44 (0)1491 832111 Fax: +44 (0)1491 829292

Email: publishing@cabi.org

CABI Publishing, CAB International,

10 East 40th Street, Suite 3203,

New York, NY 10016, USA

Tel: 2124817018 Toll free: 8005284841

Fax: 2126867993 Email: cabi-nao@cabi.org

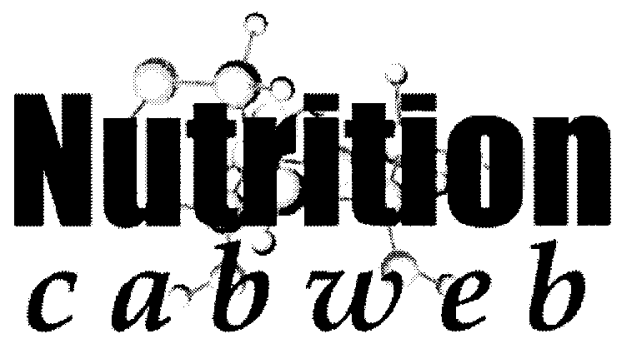

http://nutrition.cabweb.org

Available on the Internet in 1999!

Visit Nutrition CABWeb for more details and for tables of contents

\section{Institutional subscription rate:}

$\$ 310.00$ North and South America £175.00 Rest of World

A special subscription rate is azuilable for members of The Nutrition Society

$\$ 80.00$ North and South America 